\title{
Pile load test of jacked open-ended prestressed high-strength concrete pipe pile in clay
}

1 Hailei Kou PhD, MEng, BEng

Associate Professor, College of Engineering, Ocean University of China, Qingdao, China; Former Research Fellow, School of Civil and Environmental Engineering, Nanyang Technological University, Singapore

2 Jian Chu PhD, BEng

Professor, School of Civil and Environmental Engineering, Nanyang Technological University, Singapore (corresponding author: cJCHU@ntu.edu.sg)
3 Wei Guo PhD, MEng, BEng

Professor, School of Civil Engineering, Tianjin University, Tianjin, China; Former Senior Research Fellow, School of Civil and Environmental Engineering, Nanyang Technological University, Singapore

4 Mingyi Zhang PhD, MEng, BEng

Professor, Institute of Geotechnical Engineering, Qingdao Technological University, Qingdao, China
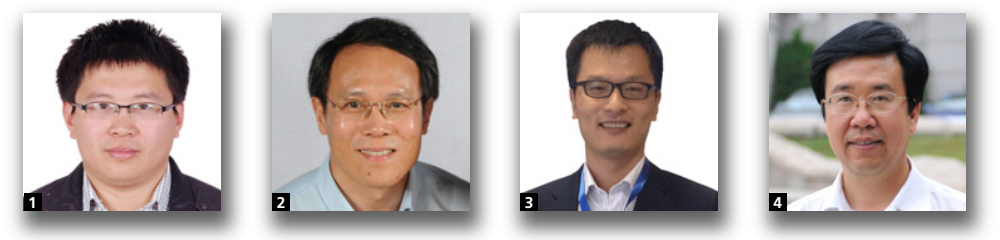

The performance of open-ended piles can be different from that of closed piles due to the effect of soil plugging. This paper presents the results of a large-scale field pile load test conducted on an open-ended pile in clay under static compressive loads. A prestressed high-strength concrete pipe pile with an outer diameter of $400 \mathrm{~mm}$ and a wall thickness of $75 \mathrm{~mm}$ was instrumented with strain sensors and installed in a marine deposit for static load testing. The measured load-transfer data during pile installation and the pile load test results are reported and analysed. The data show that the pile was in a partially plugged condition during jacking and behaved in a fully plugged mode in the static load test. The measured ultimate shaft resistance and total resistance of the test pile were 659 and $1180 \mathrm{kN}$, respectively, which were smaller than the values calculated using a previously proposed method. The back-calculated $\alpha$ and $\beta$ values (as used in the $\alpha$ and $\beta$ methods) for axial pile capacity in marine deposits were 0.42 and 0.56 , respectively.

\section{Notation}

$A \quad$ pile base area

$A_{i} \quad$ pile area between sections $i$ and $i+1$

$c \quad$ cohesion

$c^{\prime} \quad$ effective cohesion

$D$ pile diameter

E pile elasticity modulus

$f_{\mathrm{s}} \quad$ unit sleeve friction resistance

$f_{\mathrm{s} i} \quad$ local shaft resistance at section $i$

$G_{\mathrm{s}} \quad$ specific gravity

$I_{\mathrm{p}} \quad$ plasticity index

$K \quad$ average earth pressure coefficient

$K_{t} \quad$ temperature sensitivity coefficient

$K_{0} \quad$ earth pressure coefficient at rest

$K_{\varepsilon} \quad$ strain sensitivity coefficient

$L \quad$ pile length

$N_{i} \quad$ pile axial force at section $i$

$N_{i+1} \quad$ pile axial force at section $i+1$

$N_{\mathrm{kt}} \quad$ cone bearing capacity factor

$P \quad$ applied load in the method proposed by Chin (1970, 1972) $p_{\text {a }}$

$Q$

$Q_{\mathrm{b}}$

$Q_{\text {s }}$

$q_{\mathrm{c}}$

$q_{\mathrm{t}}$

$S_{\mathrm{u}}$

$w$

$\alpha$

$\beta$

$\gamma$

$\Delta$

$\Delta t$

$\Delta \varepsilon$

$\Delta \lambda_{\mathrm{B}}$

$\delta$

$\lambda_{\mathrm{BO}}$

$\sigma_{\mathrm{vo}}$

$\sigma_{\mathrm{v}}^{\prime}$

$\tau_{\mathrm{f}}$ atmospheric pressure

applied load in static load test

measured base resistance

measured shaft resistance

cone tip resistance

modified cone tip resistance

undrained shear strength

pile-head settlement in static load test

reduction factor in the $\alpha$ method

side friction factor related to lateral earth pressure

unit weight

pile-head settlement in the method proposed by

Chin (1970, 1972)

temperature change

change in strain

wavelength shift

interface frictional angle

initial Bragg wavelength of grating

total overburden pressure

in situ vertical effective stress

peak unit shaft resistance 


$\begin{array}{ll}\tau_{\mathrm{s}} & \text { unit shaft resistance } \\ \phi & \text { friction angle } \\ \phi^{\prime} & \text { effective friction angle } \\ \phi_{\mathrm{re}}^{\prime} & \text { residual friction angle }\end{array}$

\section{Introduction}

Open-ended prestressed high-strength concrete (PHC) piles are often used as a type of deep foundation in China and other Asian countries. The jacking method is preferred for the installation of PHC piles because it is free from noise, vibration and the use of slurry (Kou et al., 2015; Liu et al., 2012). However, to design displacement piles reliably is still a challenge (Randolph, 2003), primarily because of the extremely complicated physical process involved in pile installation and inadequate understanding of various construction effects (Zhang and Wang, 2009), including the effects of soil plugs and residual loads and the interaction of the pile with surrounding soils.

The formation of a soil plug plays a very important role in controlling the behaviour of open-ended pipe piles (Brucy et al., 1991; Paik and Salgado, 2003; Smith et al., 1986). A closed pipe pile, as shown in Figure 1(a), will behave like a solid pile. At the other extreme, when a pipe pile is fully plugged (Figure 1(c)), the volume of the displaced soil will be reduced markedly compared with that caused by the penetration of a solid pile (Ko and Jeong, 2015). Normally, an open-ended pipe pile is partially plugged, as shown in Figure 1(b). The development of the soil plug during installation of a pipe pile is described by the plug length ratio and the incremental filling ratio. The performance of open-ended pipe piles becomes more complicated once the degree of soil plugging is taken into account (Paik et al., 2003).

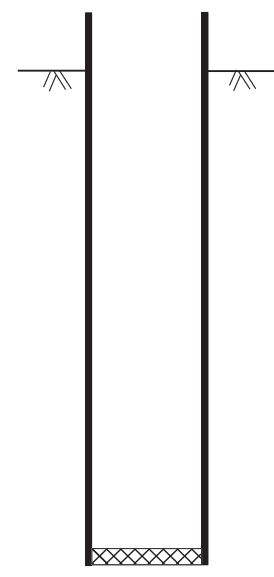

(a)

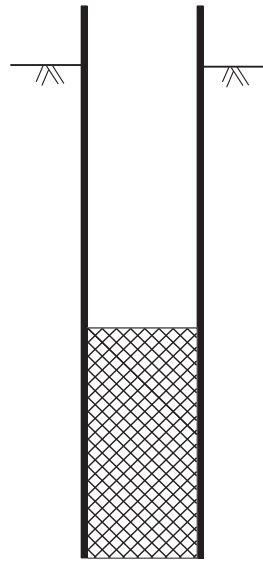

(b)

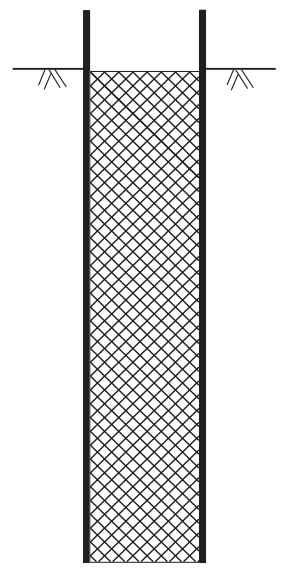

(c)
Figure 1. Models of penetration for open-ended piles: (a) fully closed pile; (b) partially plugged pile; (c) fully plugged pile
Most studies on the effect of soil plugs on pile behaviour have been conducted in sandy soil (De Nicola and Randolph, 1997; Ko and Jeong, 2015; Lehane and Gavin, 2001; Lehane and Randolph, 2002; Paik et al., 2003; Paik and Lee, 1993). In cohesive soils, research into soil plugging behaviour has focused on open-ended steel pipe piles (Doherty et al., 2010; Gallagher and Gavin, 2007; Kou et al., 2016; Miller and Lutenegger, 1997; Paikowsky et al., 1989) with a few exceptions for concrete pipe piles. One example of such is the work of Liu et al. (2011), who studied the physical formation and mechanical properties of soil plugs of jacked open-ended PHC piles and strength development over time.

The purpose of the study reported in this paper was to evaluate the effect of the soil plug on the behaviour of jacked openended piles using full-scale pile load testing. The pile load tests were carried out using an open-ended PHC pile instrumented with fibre Bragg grating (FBG) sensors in clay. The load-displacement responses of the test pile and the shaft resistance development were analysed and some commonly adopted analytical methods to predict the shaft resistance of piles were also verified.

\section{Site condition and test set-up}

\section{$2.1 \quad$ Site description}

The test site was located in Fuyang, in the southwest part of Hangzhou, China. A series of laboratory and in situ tests, including standard penetration tests (SPTs) and cone penetration tests (CPTs), was performed in situ. Figure 2 shows the soil profile as well as the SPT and CPT profiles at the test site. From the ground surface down to a depth of $15.0 \mathrm{~m}$, the soil profile consisted of a stratigraphic sequence of fill layer of $2 \cdot 0-2.5 \mathrm{~m}$ thickness and a marine deposit of 12.5 $13.0 \mathrm{~m}$ thickness. The fill layer was mainly composed of silty clay with shell fragments. The marine deposits consisted of silty clay and sandy clay with some shell fragments. The properties of the marine deposits are summarised in Table 1. The cohesion $(c)$ and friction angle $(\phi)$ were determined using the so-called quick shear test in which a soil sample was sheared in a direct shear machine without waiting for the soil to be fully consolidated. Hence the values of $c$ and $\phi$ obtained from these types of tests are different from the $c^{\prime}$ and $\phi^{\prime}$ determined from triaxial consolidated-drained or consolidated-undrained tests. For this reason, the undrained shear strength $\left(S_{\mathrm{u}}\right)$ obtained from CPTs was used in this study. The $S_{\mathrm{u}}$ value was calculated using Equation 1 (Schmertmann, 1978)

1. $S_{\mathrm{u}}=\left(q_{\mathrm{t}}-\sigma_{\mathrm{v} 0}\right) / N_{\mathrm{kt}}$

where $q_{\mathrm{t}}$ is the modified cone tip resistance from the CPT, $\sigma_{\mathrm{v} 0}$ is the total overburden pressure and $N_{\mathrm{kt}}$ is the cone bearing capacity factor. A value of 10 was used for $N_{\mathrm{kt}}$ in this work. The groundwater table was $1.5 \mathrm{~m}$ below the ground surface. 


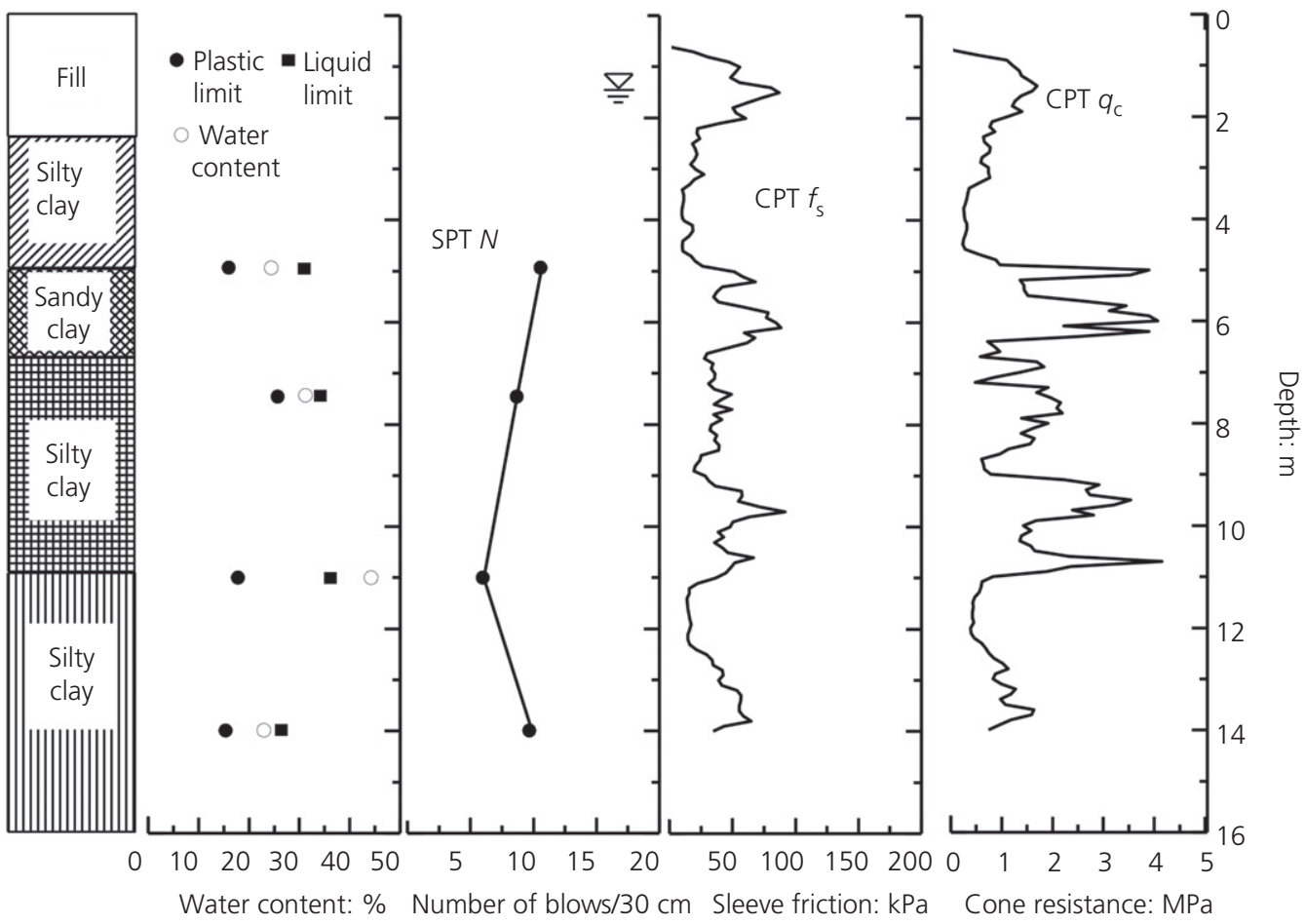

Figure 2. Soil profiles and CPT results

Table 1. Subsoil properties

\begin{tabular}{|c|c|c|c|c|c|c|}
\hline Soil type & $\gamma: \mathrm{kN} / \mathrm{m}^{3}$ & $G_{s}$ & $I_{p}: \%$ & $\mathrm{c:} \mathrm{kPa}$ & $\phi:$ degrees & $S_{u}{ }^{a}$ \\
\hline Silty clay & $19 \cdot 36$ & $2 \cdot 72$ & $12 \cdot 6$ & $14 \cdot 0$ & $21 \cdot 5$ & $50 \cdot 8$ \\
\hline Sandy clay & $18 \cdot 52$ & 2.69 & $6 \cdot 9$ & $7 \cdot 1$ & $29 \cdot 4$ & $266 \cdot 8$ \\
\hline Silty clay & $17 \cdot 07$ & $2 \cdot 74$ & $17 \cdot 2$ & $15 \cdot 8$ & 8.0 & $199 \cdot 3$ \\
\hline Silty clay & $19 \cdot 77$ & $2 \cdot 72$ & $12 \cdot 8$ & $28 \cdot 5$ & $22 \cdot 8$ & $75 \cdot 9$ \\
\hline
\end{tabular}

${ }^{a}$ Deduced from CPT data

\subsection{Test set-up}

The test pile was a precast, open-ended PHC pipe pile with an outer diameter of $400 \mathrm{~mm}$ and a wall thickness of $75 \mathrm{~mm}$. The Young's modulus and axial compressive strength of the concrete material used for the pile were 36.0 GPa and 35.9 MPa, respectively. The test pile was jacked into the ground using a jacking rig with a capacity of $6800 \mathrm{kN}$. The maximum penetration per stroke of the jack was $1.8 \mathrm{~m}$ and the penetration rate was in the range 1.0 to $1.8 \mathrm{~m} / \mathrm{min}$; the lower rate was used for the last $1-2 \mathrm{~m}$ of penetration. The penetration depth of the pile was $13.0 \mathrm{~m}$ and the pile toe was founded in the marine deposit.

Figure 3 shows a schematic illustration of the positions of the FBG sensors installed along the test pile. Seven FBG sensors were spliced with an optical fibre by a fusion splicer at planned intervals to form a line of FBG sensors. Two FBG sensor cables were attached directly opposite each other at seven levels along the pile shaft to measure the distribution and magnitude of axial stresses caused by the applied loads. Most of the FBG sensors were placed at $2.5 \mathrm{~m}$ intervals along the pile, except the last two rows near the pile toe, as shown in Figure 3. The distance from the toe or the pile head to the nearest strain gauge was $0.25 \mathrm{~m}$ to avoid the effect of pile ring. All FBG sensors attached to the test pile were bonded in place with high-strength adhesive to ensure compatibility of deformation between the pile and the sensors. Epoxy resin was then used to seal and protect the sensors from groundwater and direct contact with the soil during jacking.

The arrangement of the static load test is shown in Figure 4. The pile load test was carried out $17 \mathrm{~d}$ after pile installation in accordance with the Chinese technical code for the testing of building foundation piles (JGJ106-2014) (MCC, 2014). Fill was used as a counterweight. One hydraulic jack was used to apply the axial load and the pile-head movement with respect 


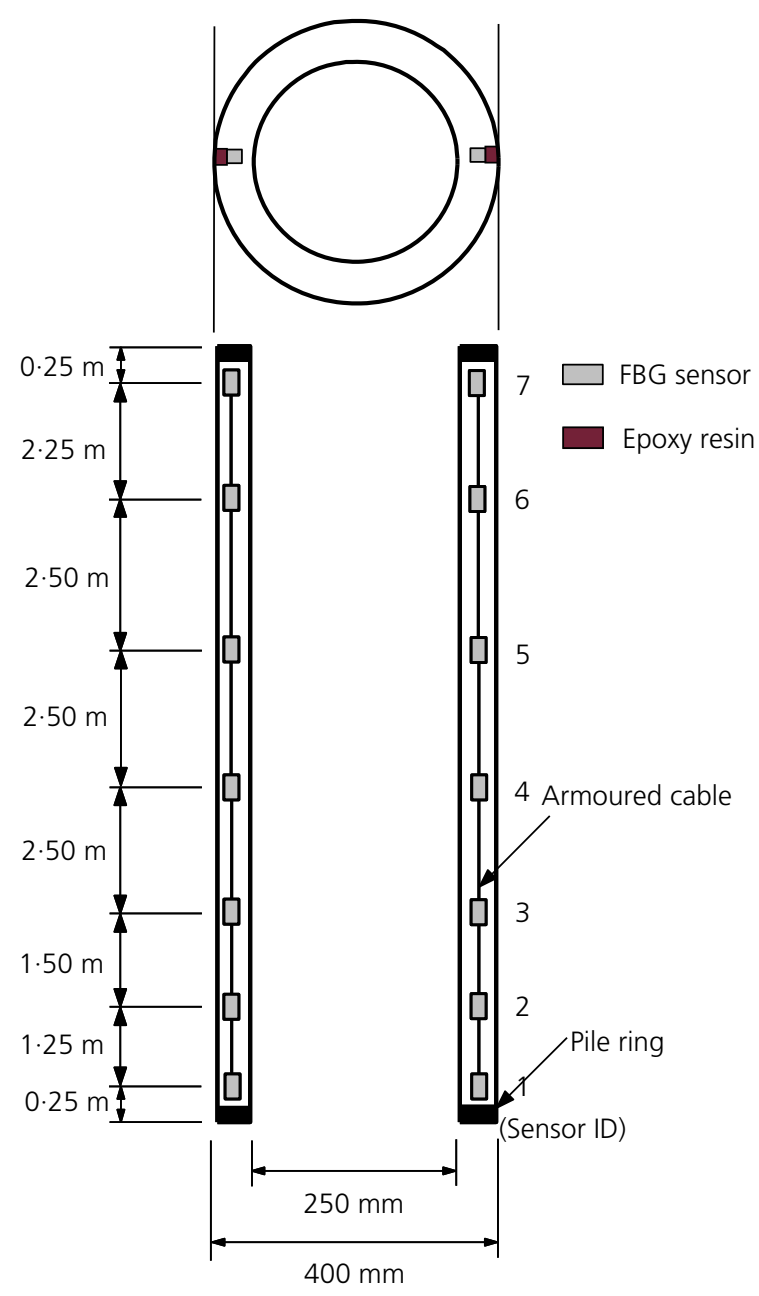

Figure 3. Schematic diagram of strain sensor installation

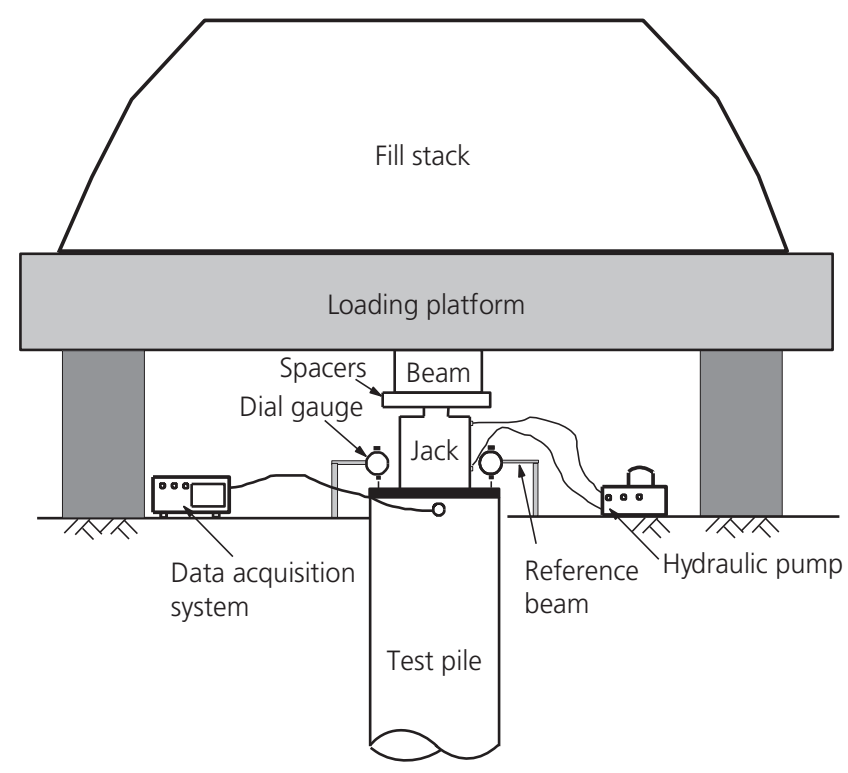

Figure 4. Schematic illustration of static loading test to the two reference beams was measured by dial gauges. The load test was carried out with maintained load without unload-reload loops using the following procedure.

(a) The load increment was one-eighth of the estimated ultimate load capacity, in steps $300,450,600,750,900$ and $1200 \mathrm{kN}$.

(b) The vertical displacement of the pile was measured for the first 5, 10, 15, 30, 45 and $60 \mathrm{~min}$ at each load step and then once every $30 \mathrm{~min}$.

(c) The difference between displacements at $30 \mathrm{~min}$ and $1 \mathrm{~h}$ after application of each load increment was calculated. If this difference was less than $0 \cdot 1 \mathrm{~mm}$, then the next load increment was applied.

(d) If the total vertical displacement was more than $40 \mathrm{~mm}$ and the displacement at the pile cap was more than five times the displacement at the beginning of the load increment, or the displacement did not stabilise after $24 \mathrm{~h}$ of loading, loading was discontinued.

\section{Test results and discussion}

\subsection{Axial loads in the test pile after installation}

During installation, the wavelength shifts of FBG sensors were calculated and used to back-calculate the axial strain of the test pile using

\section{2. $\Delta \lambda_{\mathrm{B}} / \lambda_{\mathrm{B} 0}=K_{\varepsilon} \Delta \varepsilon+K_{t} \Delta t$}

where $K_{\varepsilon}$ and $K_{t}$ are strain and temperature sensitivity coefficients, $\lambda_{\mathrm{B} 0}$ is the Bragg wavelength of the grating before jacking and $\Delta \lambda_{B}$ is the wavelength shift. In this case, the temperature change $\Delta t$ was neglected since the jacking process was completed within a few minutes. The constant strain sensitivity coefficient $K_{\varepsilon}$ was $1 \cdot 2 \mathrm{pm} / \mu \varepsilon$.

The axial loads at different levels along the pile were calculated by multiplying the measured strains by the cross-sectional area and the elastic modulus of the test pile. Figure 5 shows the axial load distribution in the pile along the depth for the final penetration depth of $13.0 \mathrm{~m}$. It can be seen from Figure 5 that the axial loads at the pile head and toe were 605.1 and $70 \cdot 1 \mathrm{kN}$, respectively. The distribution of residual loads measured along the pile after installation is also plotted in Figure 5 . The residual load at the pile toe was $42 \cdot 1 \mathrm{kN}$, which was $60.0 \%$ of the toe load. The residual load in the test pile was mostly due to the rebound of soil below the pile toe and the recovery of soil strength after soil disturbance due to pile installation (Fellenius, 2002).

\subsection{Load-displacement response during the pile load test}

For an open-ended pile under a static load, the base resistance consists of the annulus resistance and the plug resistance, as shown in Figure 6 (Fellenius, 2015). Relative movement 
Geotechnical Engineering

Volume 171 Issue GE3
Pile load test of jacked open-ended prestressed high-strength concrete pipe pile in clay

Kou, Chu, Guo and Zhang

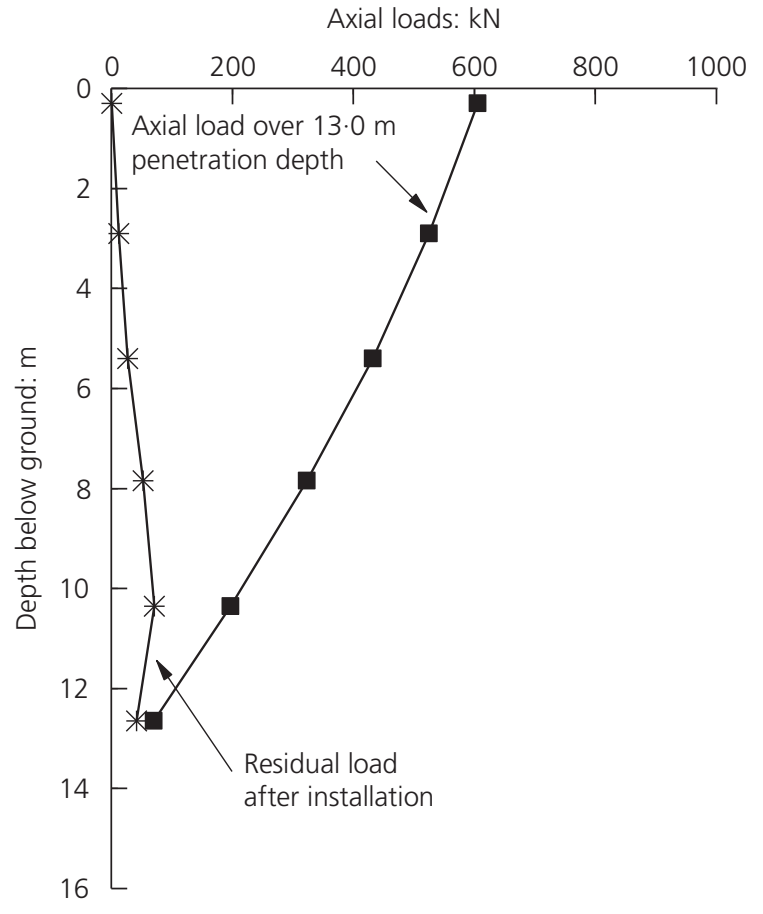

Figure 5. Distribution of axial forces over $13.0 \mathrm{~m}$ penetration depth

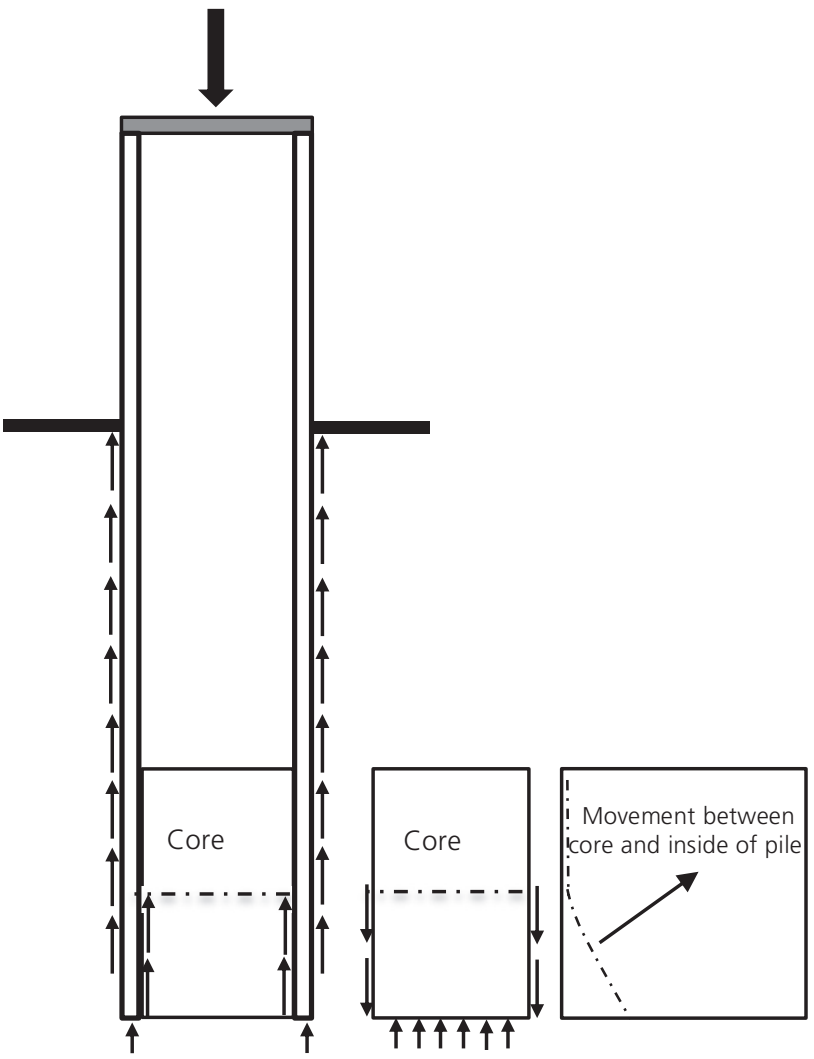

Figure 6. Force vectors in a static loading test on an open-ended pipe pile (after Fellenius, 2015) between the inner wall of a pile and the core only takes place along the length of the core that is compressed. In this case, the plug length recorded after installation was $1.70 \mathrm{~m}$ and the plug length ratio was $0 \cdot 13$. After the pile load test, the soil plug length was also measured and there was little change. It was thus considered that the inter-shaft resistance during this static load test was small and was not measured during the test.

The overall load-displacement responses of the test pile are shown in Figure 7. The base and shaft resistance measured by the FBG sensors are given in Table 2 and also plotted in Figure 7. In the compression load test, the effect of residual force was not considered. As shown in Figure 7, the load applied to the pile at the initial loading stage was mainly supported by the shaft resistance and then gradually transferred to the pile toe. The load transferred from the shaft to the base of the test pile under each pile load level is listed in Table 2. At a load of $300 \mathrm{kN}$, the base resistance of the pile was only $0.4 \%$ of the applied load whereas, at the end of test, the ratio of base resistance to applied load was about $45 \cdot 1 \%$. The lack of substantial increase in the shaft resistance during the pile load test could be explained by the $17 \mathrm{~d}$ waiting period after pile

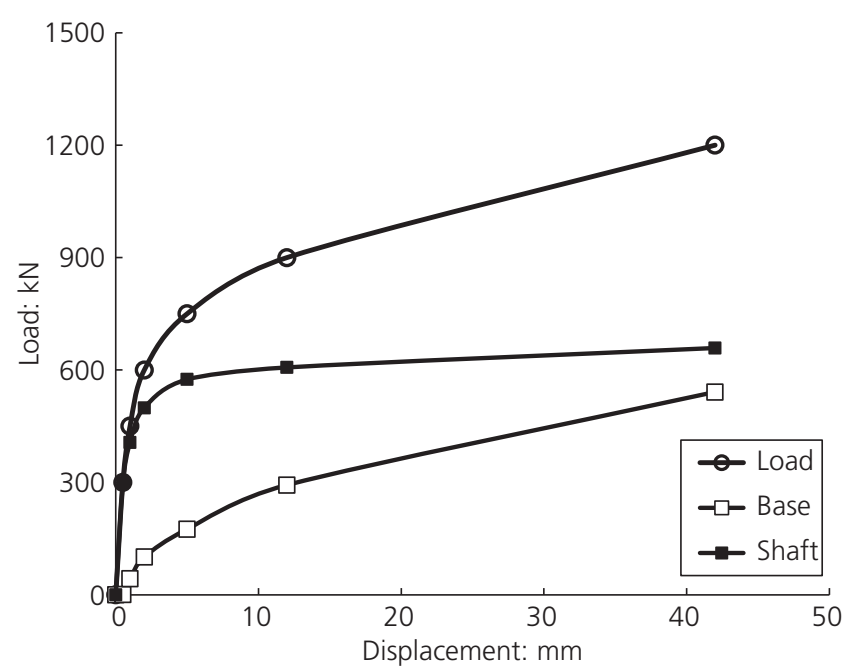

Figure 7. Load-displacement responses of the test pile during the pile load test

Table 2. Summary of measured base resistance

\begin{tabular}{lcccc}
$\begin{array}{l}\text { Pile load } \\
\text { Q: kN }\end{array}$ & $\begin{array}{c}\text { Shaft } \\
\text { resistance } \\
\mathbf{Q}_{\mathbf{s}} \text { : kN }\end{array}$ & $\begin{array}{c}\text { Base } \\
\text { resistance } \\
\mathbf{Q}_{\mathbf{b}}: \mathbf{k N}\end{array}$ & $\mathbf{Q}_{\mathbf{s}} / \mathbf{Q}: \%$ & $\mathbf{Q}_{\mathbf{b}} / \mathbf{Q}: \%$ \\
\hline 300 & 299 & 1 & $99 \cdot 6$ & $0 \cdot 4$ \\
450 & 407 & 43 & $90 \cdot 4$ & $9 \cdot 6$ \\
600 & 500 & 100 & $83 \cdot 3$ & $16 \cdot 7$ \\
750 & 575 & 175 & $76 \cdot 7$ & $23 \cdot 3$ \\
900 & 607 & 293 & $67 \cdot 4$ & $32 \cdot 6$ \\
1200 & 659 & 541 & $54 \cdot 9$ & $45 \cdot 1$ \\
& & & &
\end{tabular}


installation. During this time, a major increase in shaft resistance due to the set-up effect would have occurred, as indicated by Liu et al. (2011). In a case study reported by Liu et al. (2012), it was also observed that the radial effective stress after installation increased only slightly, possibly because of the plugging effect. The base resistance at the end of the test was rather high, as shown in Figure 7 and Table 2. The data may have been affected by temperature. As already mentioned, the temperature effect was not considered in the analysis as the pile was installed quickly. However, as the sensors near the toe were switched on at the ground level and the pile was installed into the soil more than $10 \mathrm{~m}$ below the ground surface, the temperature difference could potentially have led to significant errors in the interpreted strains. Using the FBG instruments, the distribution of local resistances in different soil layers along the test pile during the pile load test could be determined. The shear stresses along different sections of the piles are plotted against the normalised pile-head settlement $(w / D)$ in Figure 8. It can be seen from this figure that the shaft resistance along the pile would not increase much with further displacement.

\subsection{Interpretations of ultimate pile resistance}

The ultimate bearing capacity of a pile as determined from a pile load test is based on the pile load at a given settlement. Using the Chinese code for the testing of building foundation piles (MCC, 2014), the ultimate bearing capacity of the pile (or the ultimate pile resistance) was determined to be $1180 \mathrm{kN}$, which was the load at which the pile settled by $10 \%$ of the pile diameter $(40 \mathrm{~mm})$. The ultimate base and shaft resistance at the displacement of $40 \mathrm{~mm}$ were 521 and $659 \mathrm{kN}$, respectively.

The method proposed by Chin $(1970,1972)$ was also adopted to obtain the ultimate load using the static pile load test

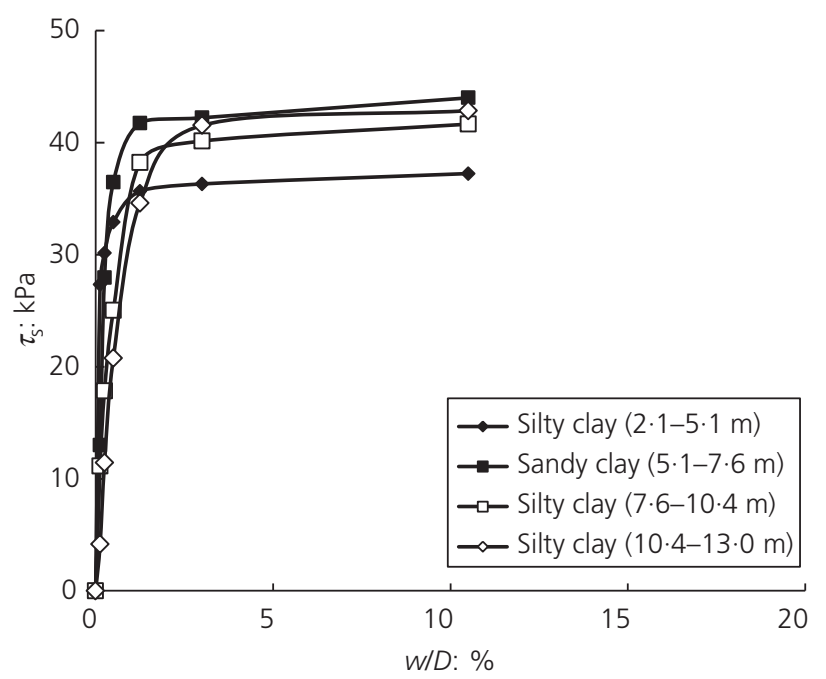

Figure 8. Mobilisation of unit shaft resistance $\left(\tau_{\mathrm{s}}\right)$ in different soil layers along the test pile results. In this method, the settlement $\Delta$ at each load $P$ is plotted against $\Delta / P$, and this plot for the pile load test is shown in Figure 9. It can be seen that the data points fitted two straight lines, which indicates that the pile was supported by combined shaft friction and end bearing. According to Chin (1972), the base resistance requires higher settlement to be mobilised than the shaft resistance, thus the first straight line is associated with the shaft resistance while the second line is associated with the total pile resistance. Using the slopes of these two straight lines, the ultimate shaft and total resistances of the pile were determined to be 820 and $1432 \mathrm{kN}$, respectively. The base resistance was then calculated to be $612 \mathrm{kN}$, $13 \%$ higher than the base resistance measured by the pile load test shown in Figure 7.

The Davisson offset limit (Davisson, 1972) is also widely used for the interpretation of axial compressive load tests on pile foundations. As shown in Figure 10, the elastic line was intentionally fitted to the initial straight-line portion of the loaddeflection curve, resulting in gross elastic compression $(P L / A E)$ of the test pile, where $P$ is the applied load; $L$ is the pile length; $A$ is the pile base area and $E$ is pile elasticity modulus. The Davisson offset limit line was constructed by offsetting the elastic line by a distance of $3.8 \mathrm{~mm}$ plus the pile diameter divided by 120 . According to the Davisson offset limit, the axial compressive capacity of the pile was $900 \mathrm{kN}$. It

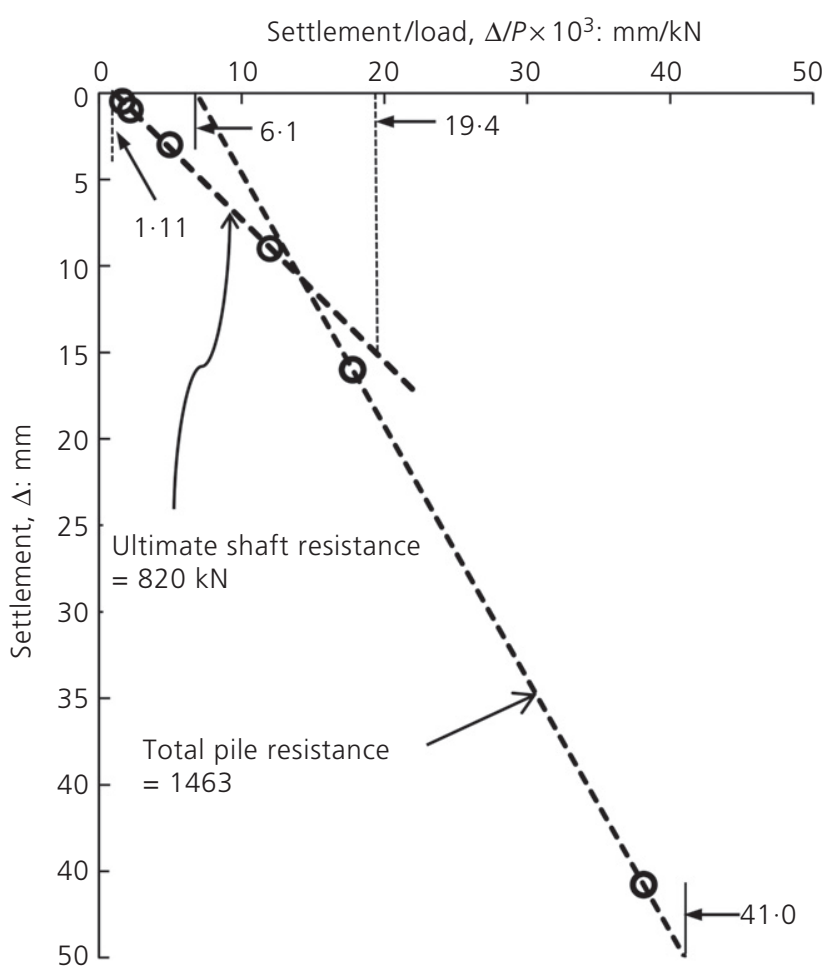

Figure 9. Analysis of load-settlement curve from pile load test using the method proposed by Chin $(1970,1972)$ 


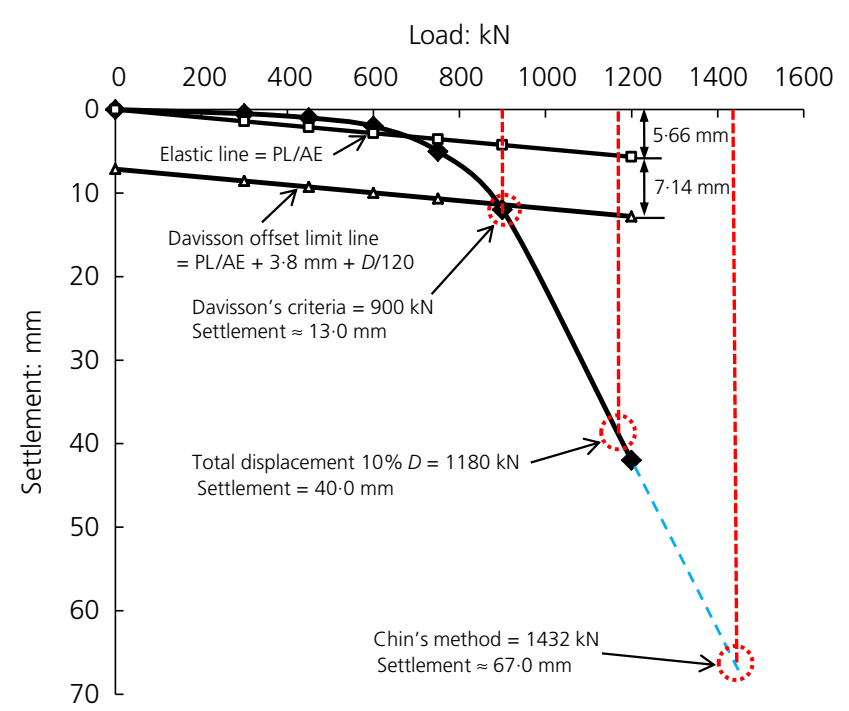

Figure 10. Analysis of load-settlement curve from pile load test using the method proposed by Davisson (1972)

is thus clear that the ultimate pile resistance from Davisson's method is smaller than that calculated using Chin's method $(1432 \mathrm{kN})$ or the Chinese code method $(1180 \mathrm{kN})$. Fellenius (1980) and Borel et al. (2004) also observed that Chin's method could overpredict the shaft resistance and ultimate pile capacity. However, it should be noted that the settlement at which the ultimate pile capacity is obtained is different in the three interpretation methods. As shown in Figure 10, these settlements were $13 \cdot 0,40 \cdot 0$ and $67 \cdot 0 \mathrm{~mm}$ respectively using the method of Davisson, the Chinese code and the method proposed by Chin.

\subsection{Distribution of shaft resistance in the test pile}

Assuming that the axial load is distributed uniformly along the pile shaft between the strain gauge locations during a pile load test, the local shaft resistance $f_{\mathrm{s} i}$ can be evaluated as

3. $f_{s i}=\left(N_{i}+1-N_{i}\right) / A_{i}$

where $N_{i}$ is the axial force in the pile shaft located at section $i$, $N_{i+1}$ is the axial force in the pile shaft located at section $i+1$ and $A_{i}$ is the area of pile located between sections $i$ and $i+1$.

Figure 8 shows that the shaft resistance increased rapidly with increasing pile-head displacement initially, but reached a plateau after once $w / D$ was greater than $3 \%$. As shown in Figure 8 , the peak local shaft resistance was $44 \mathrm{kPa}$ in silty clay and $37 \mathrm{kPa}$ in sandy clay. The distribution of peak shaft resistance in different soil layers is shown in Figure 11. The peak shaft resistances in the different soil layers after pile installation were also calculated using Equation 3 and these are shown in Figure 11 for comparison. It can be seen that the

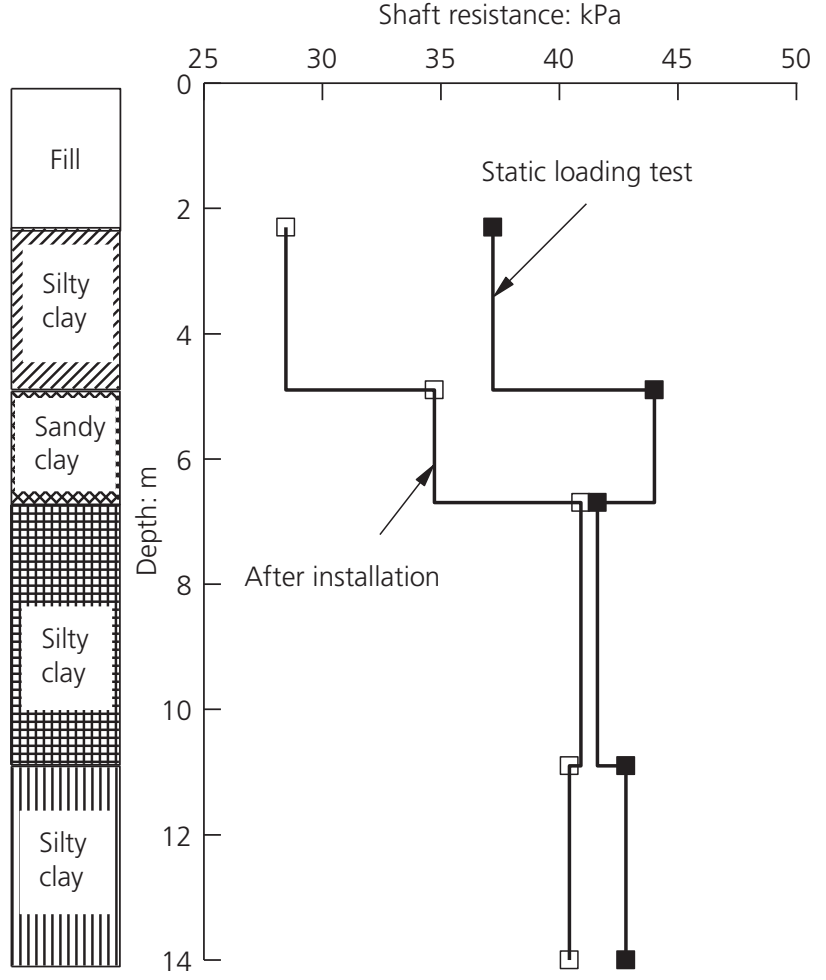

Figure 11. Distribution of local shaft resistance along the $13.0 \mathrm{~m}$ penetration depth

shaft resistances during the pile load test were higher, mainly because of the set-up effect caused by the waiting period of $17 \mathrm{~d}$, as explained previously. Similar observations were also made by Komurka, et al. (2003), Liu et al. (2011, 2012) and Gavin et al. (2013).

The pile load test data were also used to verify some commonly adopted analytical methods for predicting the axial load resistance of piles. The first, called the $\alpha$ method, is used to calculate the peak unit shaft resistance $\left(\tau_{\mathrm{f}}\right)$ of displacement piles in clay (Chandler, 1968; Gavin et al., 2009) using

4. $\tau_{\mathrm{f}}=\alpha S_{\mathrm{u}}$

where $\alpha$ is a reduction factor and $S_{\mathrm{u}}$ is the in situ undrained shear strength of soil (shown in Table 1).

The second method, the $\beta$ method, is used to calculate the peak unit shaft resistance of displacement piles using earth pressure theory, and is given by (Burland, 1973; Meyerhof, 1976)

5. $\tau_{\mathrm{f}}=\beta \sigma_{\mathrm{v}}^{\prime}$

where $\beta$ is a side friction factor, related to the lateral earth pressure, and $\sigma_{\mathrm{v}}^{\prime}$ is the in situ vertical effective stress of soil, which is calculated using a unit weight of $18.68 \mathrm{kN} / \mathrm{m}^{3}$. 


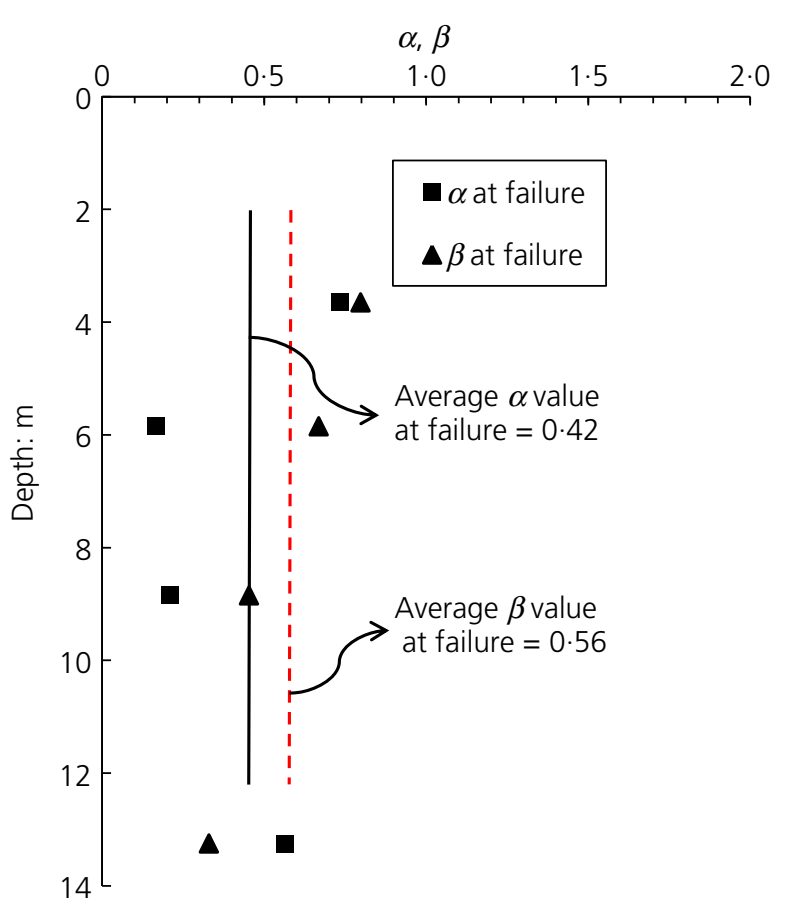

Figure 12. Mobilisation of $\alpha$ and $\beta$ along the test pile

The values of $\alpha$ and $\beta$ are normally estimated using $S_{\mathrm{u}}$ and the interface friction angle, respectively, as in the following equations proposed by Kulhawy and Jackson (1989) and Chandler (1968)

6. $\alpha=0 \cdot 21+0 \cdot 26 p_{\mathrm{a}} / S_{\mathrm{u}}(\alpha \leq 1)$

7. $\beta=K \tan \delta$

where $p_{\mathrm{a}}$ is atmospheric pressure, $K$ is the average coefficient of earth pressure on the pile shaft and $\delta$ is the interface frictional angle. For normally consolidated clay, assuming $K=K_{0}=1-\sin \phi^{\prime}$ and $\delta=\phi^{\prime}$, as suggested by Burland (1973), Equation 7 becomes

8. $\beta=\left(1-\sin \phi^{\prime}\right) \tan \phi^{\prime}=\left(1-\sin \phi_{\mathrm{re}}^{\prime}\right) \tan \phi_{\mathrm{re}}^{\prime}$

where $K_{0}$ is the earth pressure coefficient at rest and $\phi^{\prime}$ is the effective friction angle of the soil. As suggested by Burland (1973) and Tomlinson (1971), failure takes place in the remoulded soil close to the shaft surface, so that the $\phi^{\prime}$ can be taken as a residual friction angle $\phi_{\mathrm{re}}^{\prime}$ which may be calculated as $\sin \phi_{\mathrm{re}}^{\prime} \approx 0.8-0.094 \ln I_{\mathrm{p}}$, in which $I_{\mathrm{p}}$ is the plasticity index (Mitchell, 1976). Using Equations 6 and 8, $\alpha$ and $\beta$ value were calculated as 0.47 and 0.57 , respectively.

Using the measured shaft resistances shown in Figure 8, the $\alpha$ and $\beta$ values were back-calculated and the values are plotted against depth in Figure 12. The average back-calculated $\alpha$ value was $0 \cdot 42$, which is comparable to the theoretical value of $0 \cdot 47$. The average back-calculated $\beta$ value was $0 \cdot 56$, which is also close to the theoretical value of $0 \cdot 57$.

\section{Conclusions}

A field study on an instrumented, open-ended PHC pile jacked into clay was carried out. The performance of the test pile was monitored during installation and during a pile load test. The major observations from this study can be summarised as follows.

(a) The performance of an open-ended pile is more complicated than that of a closed pile due to the effect of the soil plug. The axial load applied to the pile was sustained by the shaft initially and the subsequent increase in the axial load with further pile displacement was mainly taken by the base. At the end of the pile load test, the base took $45 \%$ of the total applied load.

(b) The ultimate pile resistance determined from the pile load test using different methods corresponded to the pile load resistance taken at different settlements. The ultimate pile resistance determined using the methods of Davisson (1972), the Chinese code (MCC, 2014) and the method proposed by Chin $(1970,1972)$ were 900,1180 and $1432 \mathrm{kN}$, which corresponded to pile displacements of $13 \cdot 0,40 \cdot 0$ and $67 \cdot 0 \mathrm{~mm}$, respectively. The base resistance of the pile could also be estimated using Chin's method: the estimated value of $612 \mathrm{kN}$ was $13 \%$ higher than the measured value of $541 \mathrm{kN}$.

(c) Using the pile load test data, the $\alpha$ and $\beta$ values as used in the $\alpha$ and $\beta$ methods were back-calculated. The average $\alpha$ and $\beta$ values in the marine deposits were found to be $0 \cdot 42$ and 0.56 , respectively, which are comparable to the theoretical values of 0.47 and 0.57 .

\section{Acknowledgements}

The authors would like to acknowledge gratefully that the work presented in this paper was supported by a grant from the NTU-JTC Industrial Infrastructure Innovation Centre (I3C) (ID: I3C131E2), grants from the National Natural Science Foundations of China (51408439 and 51078196) and the Weifang Scientific and Technology Development Program (2015GX012).

\section{REFERENCES}

Brucy F, Meunier J and Nauroy JF (1991) Behavior of pile plugs in sandy soils during and after driving. Proceedings of 23rd Offshore Technology Conference, Houston, TX, USA, OTC6514, pp. 145-154.

Borel S, Bustamante M and Gianeselli L (2004) An appraisal of the Chin method based on 50 instrumented pile tests. Ground Engineering 37(1): 22-26.

Burland J (1973) Shaft friction of piles in clay - a simple fundamental approach. Ground Engineering 6(3): 30-32. 
Chandler RJ (1968) The shaft friction of piles in cohesive soil in terms of effective stress. Civil Engineering and Public Works Review 63(738): 48-51.

Chin FK (1970) Estimation of the ultimate load of piles from tests not carried to failure. Proceedings of the 2nd Southeast Asian Conference on Soil Engineering. SEAGS, Bangkok, Thailand, pp. 81-90.

Chin FK (1972) The inverse slope as a prediction of ultimate bearing capacity of piles. Proceedings of the 3rd Southeast Asian Conference on Soil Engineering. SEAGS, Bangkok, Thailand, pp. 83-91.

Davisson MT (1972) High capacity piles. Proceedings of a Lecture Series on Innovations in Foundation Construction. American Society of Civil Engineers, Chicago, IL, USA, pp. 81-112.

De Nicola A and Randolph MF (1997) The plugging behaviour of driven and jacked piles in sand. Géotechnique 47(4): 841-856

Doherty P, Gavin K and Gallagher D (2010) Field investigation of the undrained base resistance of pipe piles in clay. Proceedings of the Institution of Civil Engineers - Geotechnical Engineering 163(1): 13-22, http://dx.doi.org/10.1680/geng.2010.163.1.13.

Fellenius BH (1980) The analysis of results from routine pile load tests. Ground Engineering 113(6): 19-31.

Fellenius BH (2002) Determining the true distributions of load in instrumented piles. In International Deep Foundation Congress, An International Perspective on Theory, Design, Construction, and Performance (O'Neill MW and Townsend FC (eds)). American Society of Civil Engineers, Reston, VA, USA, Geotechnical Special Publication 116, vol. 2, pp. 1455-1470.

Fellenius BH (2015) Discussion of 'Plugging effect of open-ended piles in sandy soil'. Canadian Geotechnical Journal 52(5): 664-667.

Gallagher D and Gavin K (2007) An investigation of the effect of partial plugging during installation on the shaft capacity of open-ended piles in soft clay. In Contemporary Issues in Deep Foundations. American Society of Civil Engineers, Reston, VA, USA, pp. 1-8.

Gavin KG, Cadogan D and Casey P (2009) Shaft capacity of continuous flight auger piles in sand. Journal of Geotechnical and Geoenvironmental Engineering 135(6): 790-798.

Gavin KG, Igoe DJP and Kirwan L (2013) The effect of ageing on the axial capacity of piles in sand. Proceedings of the Institution of Civil Engineers - Geotechnical Engineering 166(2): 122-130, http://dx.doi.org/10.1680/geng.12.00064.

Ko J and Jeong S (2015) The plugging effect of open-ended piles in sandy soil. Canadian Geotechnical Journal 52(5): 535-547.

Komurka VE, Wagner AB and Edil T (2003) Estimating SoillPile Set-Up. Wisconsin Highway Research Program, Madison, WI, USA, Report No. 03-05.

Kou HL, Guo W and Zhang MY (2015) Pullout performance of GFRP anti-floating anchor in weathered soil. Tunnelling and Underground Space Technology 49: 408-416, https://doi.org/10.1016/j.tust.2015. 06.001 .

Kou HL, Chu J, Guo W and Zhang MY (2016) Field study of residual forces developed in pre-stressed high-strength concrete (PHC) pipe piles. Canadian Geotechnical Journal 53(4): 696-707.

Kulhawy FH and Jackson CS (1989) Some observations on undrained side resistance of drilled shafts. Foundation Engineering: Current Principles and Practices. American Society of Civil Engineers, New York, NY, USA, pp. 1011-1025.

Lehane BM and Gavin KG (2001) Base resistance of jacked pipe piles in sand. Journal of Geotechnical and Geoenvironmental Engineering 127(6): 473-480.

Lehane BM and Randolph MF (2002) Evaluation of a minimum base resistance for driven pipe piles in siliceous sand. Journal of Geotechnical and Geoenvironmental Engineering 128(3): 198-205.
Liu JW, Zhang ZM, Yu F and Lin CG (2011) Effect of soil set-up on the capacity of jacked concrete pipe piles in mixed soil. Journal of Zhejiang University - Science A 12(8): 637-644.

Liu JW, Zhang ZM, Yu F and Xie ZZ (2012) Case history of installing instrumented jacked open-ended piles. Journal of Geotechnical and Geoenvironmental Engineering 138(7): 810-820.

MCC (Ministry of Construction of the People's Republic of China) (2014) JGJ106-2014: Technical code for building pile foundations. China Building Industry Press, Beijing, People's Republic of China.

Meyerhof GG (1976) Bearing capacity and settlement of pile foundations. Journal of Geoenvironmental Engineering Division ASCE 102(3): 195-228.

Miller GA and Lutenegger AJ (1997) Influence of pile plugging on skin friction in overconsolidated clay. Journal of Geotechnical and Geoenvironmental Engineering 123(6): 525-533.

Mitchell JK (1976) Fundamentals of Soil Behavior. Wiley, New York, NY, USA.

Paik KH and Lee SR (1993) Behavior of soil plugs in open-ended model piles driven into sands. Marine Georesources \& Geotechnology 11(4): 353-373.

Paik KH and Salgado R (2003) Determination of the bearing capacity of open-ended piles in sand. Journal of Geotechnical and Geoenvironmental Engineering 129(1): 46-57.

Paik K, Salgado R, Lee J and Kim B (2003) Behavior of open-and closed-ended piles driven into sands. Journal of Geotechnical and Geoenvironmental Engineering 129(4): 296-306.

Paikowsky SG, Whitman RV and Baligh MM (1989) A new look the phenomenon of offshore pile plugging. Marine Georesources \& Geotechnology 8(3): 213-230.

Randolph MF (2003) Science and empiricism in pile foundation design. Géotechnique 53(10): 847-875, http://dx.doi.org/10.1680/ geot.2003.53.10.847.

Schmertmann JH (1978) Guidelines for Cone Penetration Test (Performance and Design). US Department of Transportation, Federal Highways Administration, Washington, DC, USA, FHWA-TS-78-209 Final Report.

Smith IM, To P and Wilson SM (1986) Plugging of pipe piles. Proceeding of the 3rd International Conference on Numerical Method in Offshore Piling, Nantes, France, pp. 53-73.

Tomlinson MJ (1971) Some effects of pile driving on skin friction. In Behavior of Piles. Thomas Telford Publishing, London, UK, pp. 107-114.

Zhang LM and Wang H (2009) Field study of construction effects in jacked and driven steel H-piles. Géotechnique 59(1): 63-69, http://dx.doi.org/10.1680/geot.2008.T.029.

\section{How can you contribute?}

To discuss this paper, please email up to 500 words to the editor at journals@ice.org.uk. Your contribution will be forwarded to the author(s) for a reply and, if considered appropriate by the editorial board, it will be published as discussion in a future issue of the journal.

Proceedings journals rely entirely on contributions from the civil engineering profession (and allied disciplines). Information about how to submit your paper online is available at www.icevirtuallibrary.com/page/authors, where you will also find detailed author guidelines. 